\title{
MODEL MATEMATIS DEGRADASI NAPTALENA OLEH BAKTERI Pseudomonas Sp HB
}

\author{
H. Budiastuti*
}

\section{Abstrak}

Sifat racun dan karsinogenik dari naptalena serta rendahnya solubilitas senyawa ini dalam air (31,5 ppm) merupakan persoalan dalam degradasi senyawa organik ini secara biologis. Dalam kasus seperti ini bantuan model matematis dalam memprediksi profil biodegradasi dan penetuan parameter kinetis degradasi senyawa beracun ini sangat berguna. Dari pemodelan secara matematis didapat harga kecepatan pertumbuhan maksimum $\left(\mu_{\max }\right)$ dari Pseudomonas Sp HB sebesar 0,20 jam ${ }^{-1}$. Koefisien perpindahan massa $(\mathrm{ka})$ dan koefisien saturasi $(\mathrm{Ks})$ masing-masing sebesar $3780 \mathrm{jam}^{-1}$ dan $1,84 \mathrm{mg} / \mathrm{l}$. Simulasi matematis dengan bantuan persamaan diferensial orde ke 4 dan ke 5 dari RungeKutta dalam sofware MATLAB dapat memprediksi pertumbuhan bakteri dan utilisasi larutan naptalena dengan akurasi yang cukup tinggi.

Kata kunci : degradasi; model matematis; naptalena; Pseudomonas Sp HB

\section{Pendahuluan}

Penelitian ini merupakan kelanjutan dari dua penelitian sebelumnya. Identifikasi dan karakteristik dari bakteri pengkonsumsi naptalena (Pseudomonas $S p H B)$ dapat dilihat pada penelitian pertama (Budiastuti, 2004) sedangkan pengaruh penambahan surfaktan non-ionik pada degradasi naptalena dibahas pada penelitian kedua (Budiastuti, 2005). Naptalena menjadi fokus utama dalam serangkaian penelitian ini dikarenakan senyawa ini merupakan satu dari 16 senyawa hidrokarbon aromatik polisiklis (polycyclic aromatic hydrocarbon/PAH) yang harus dimonitor di buangan industri (Aitken et al., 1997; Mohan et al., 2005; Mueller et al., 1991). Senyawa hidrokarbon dengan 2 buah cincin benzen yang menyatu melalui 2 atom karbon ini merupakan senyawa beracun yang sangat mencemari lingkungan (Meckenstock et al., 2000; Rockne and Strand, 2001; Faust, 1993).

Secara umum biodegradasi dipilih sebagai metode penguraian senyawa beracun ini karena degradasi secara biologis merupakan cara penguraian senyawa organik yang ramah lingkungan (Aitken et al., 1997; Edgehill, 1992) Sifat racun dari naptalena dapat dihilangkan dengan cara pemecahan rantai karbon senyawa ini saat dikonsumsi oleh mikroorganisme sebagai sumber karbon bagi pertumbuhannya. Namun sayangnya senyawa naptalena merupakan senyawa hidrokarbon yang mempunyai solubilitas yang rendah dalam air, yakni sebesar 31,5 ppm (Aitken et al., 1997; Mueller et al., 1989) sehingga senyawa ini memerlukan waktu yang lama untuk dapat didegradasi secara biologis. Walaupun penambahan surfaktan dapat mempersingkat waktu biodegradasi (Budiastuti, 2005) model matematis akan sangat membantu dalam memprediksi penguraian naptalena secara biologis dan dalam penentuan parameter kinetisnya. Sehingga waktu yang lama dalam melakukan percobaan di laboratorium dan kesulitan dalam penentuan koefisien degradasi dapat dihindari.

\section{Peralatan dan Metode Penelitian}

Inokulum dari Pseudomonas sp HB dipersiapkan hingga mencapai kekeruhan sekitar 1 atau jumlah sel sebanyak $1 \times 10^{9}$ sebelum digunakan dalam percobaan. Sepuluh persen $(10 \%)$ inokulum dipakai sebagai patokan dalam setiap percobaan yang dilakukan secara duplikasi.

Metode pengukuran biomasa pendegradasi naptalena (Pseudomonas sp $H B$ ) dan pengukuran konsentrasi naptalena sama dengan metode pengukuran variabel-variabel ini pada penelitian sebelumnya (Budiastuti, 2004). Cell yield $\left(\mathrm{Y}_{\mathrm{X} / \mathrm{S}}\right)$ ditentukan secara gravimetris bukan berdasarkan rasio antara perbedaan pengukuran biomasa dan perbedaan pengukuran naptalena sebelum dan sesudah percobaan seperti yang dilakukan pada penelitian sebelumnya (Budiastuti, 2004). Kecepatan pertumbuhan spesifik maksimum $\left(\mu_{\max }\right)$ secara percobaan diperoleh dari slope kurva logaritmik pertumbuhan bakteri pada fase ekponensial. Untuk ketelitian hasil, dua macam naptalena yang digunakan pada penentuan $\mu_{\max }$ yakni naptalena terlarut maupun naptalena dalam bentuk butiran halus.

Persamaan matematis yang digunakan untuk menentukan/menghitung parameter model kinetis adalah persamaan (1) $\mathrm{s} / \mathrm{d}$ (3). Persamaan (1) digunakan untuk menggambarkan kurva model utilisasi naptalena oleh bakteri Pseudomonas sp HB.

$$
\mathrm{S}=\mathrm{S}_{0}-\frac{\mathrm{N}_{0}}{\mathrm{Y}_{\mathrm{X} / \mathrm{S}}}\left(\mathrm{e}^{\mu \mathrm{t}}-1\right)
$$

\footnotetext{
${ }^{\text {*) }}$ Politeknik Negeri Bandung 


$$
\begin{aligned}
& \ln \frac{m}{m_{0}}=-\left(\frac{k a}{\rho}\right)\left\{S_{\text {sat }}\left(t-t_{0}\right)-\int_{t_{0}}^{t} S d t\right\} \\
& \frac{\left(K_{S} Y_{X / S}+S_{0} Y_{X / S}+X_{0}\right)}{\left(Y_{X / S} S_{0}+X_{0}\right)} \ln \frac{X}{X_{0}} \\
& -\frac{\left(\mathrm{K}_{\mathrm{S}} \mathrm{Y}_{\mathrm{X} / \mathrm{S}}\right)}{\left(\mathrm{Y}_{\mathrm{X} / \mathrm{S}}+\mathrm{X}_{0}\right)} \ln \frac{\left(\mathrm{Y}_{\mathrm{X} / \mathrm{S}} \mathrm{S}_{0}+\mathrm{X}_{0}-\mathrm{X}\right)}{\left(\mathrm{Y}_{\mathrm{X} / \mathrm{S}} \mathrm{S}_{0}\right)}=\mu_{\max } \mathrm{t}
\end{aligned}
$$

Pencocokan kurva utilisasi naptalena hasil model dan kurva utilisasi naptalena hasil percobaan digunakan untuk menentukan kecepatan pertumbuhan spesifik maksimum $\left(\mu_{\max }\right)$ Pseudomonas $s p H B$. Persamaan (2) digunakan untuk menghitung koefisien perpindahan masa (ka) dan persamaan (3) untuk menghitung koefisien saturasi $(\mathrm{Ks})$ dengan data $\mathrm{Y}_{\mathrm{X} / \mathrm{s}}$ dan $\mu_{\max }$ pada penentuan sebelumnya.

Persamaan diferensial orde ke 4 dan ke 5 dari Runge-Kutta dalam sofware MATLAB digunakan untuk memperoleh data model matematis sedangkan persamaan yang digunakan untuk menggambarkan model dinamis dari pertumbuhan bakteri, utilisasi larutan naptalena, dan profil perubahan naptalena padatan terhadap waktu adalah masing-masing persamaan deferensial (4), (5) dan (6).

$$
\begin{gathered}
\frac{\mathrm{dX}}{\mathrm{dt}}=\mu_{\max }\left\{\frac{\mathrm{SX}}{\mathrm{K}_{\mathrm{S}}+\mathrm{S}}\right\} \\
\frac{\mathrm{dS}}{\mathrm{dt}}=\mathrm{k}_{\mathrm{a}}\left\{\frac{\mathrm{m}}{\rho}\right\}\left\{\mathrm{S}_{\mathrm{sat}}-\mathrm{S}\right\}-\frac{\mathrm{X}}{\mathrm{Y}_{\mathrm{X} / \mathrm{S}}} \mu_{\max }\left\{\frac{\mathrm{SX}}{\mathrm{K}_{\mathrm{S}}+\mathrm{S}}\right\} \\
\frac{\mathrm{dm}}{\mathrm{dt}}=-\mathrm{k}_{\mathrm{a}}\left\{\frac{\mathrm{m}}{\rho}\right\}\left\{\mathrm{S}_{\mathrm{sat}}-\mathrm{S}\right\}
\end{gathered}
$$

Dari data yang diperoleh dibuat kurva simulasi dari pertumbuhan bakteri, utilisasi larutan naptalena dan naptalena padatan oleh bakteri Pseudomonas Sp $H B$. Kurva simulasi yang dibangun kemudian dibandingkan dengan kurva hasil percobaan untuk mengetahui akurasi prediksi dari model.

\section{Hasil dan Pembahasan \\ Cell Yield secara gravimetris}

Dari 7 kali penentuan cell yield $\left(\mathrm{Y}_{\mathrm{X} / \mathrm{S}}\right)$ secara gravimetris didapat harga rata-rata sebesar $0,70 \pm 0,02$ $\mathrm{g}$ sel/g naptalena. Harga $Y_{\mathrm{X} / \mathrm{s}}$ yang didapatkan dengan menggunakan metode rasio antara perbedaan pengukuran biomasa dan perbedaan pengukuran naptalena sebelum dan sesudah percobaan (Budiastuti, 2004) sebesar $0,88 \pm 0,05 \mathrm{~g} \mathrm{sel} / \mathrm{g}$ naptalena. Perbedaan harga $\mathrm{Y}_{\mathrm{X} / \mathrm{S}} \mathrm{di}$ atas akibat perbedaan metode pengukuran yang digunakan. Namun karena dianggap penentuan $Y_{X / S}$ dengan metode rasio dapat menghasilkan kesalahan yang relatif lebih besar dari pada penentuan $Y_{X / S}$ secara gravimetris maka harga $\mathrm{Y}_{\mathrm{X} / \mathrm{S}}$ sebesar $0,70 \mathrm{~g}$ sel/g naptalena yang digunakan sebagai input simulasi model.

Ada 2 alasan mengapa metode rasio dianggap menghasilkan kesalahan yang relatif lebih besar. Alasan yang pertama adalah penentuan kenaikan berat sel dihitung berdasarkan selisih pengukuran $\mathrm{A}_{600}$ yang nilainya berdekatan satu sama lain. Persen kesalahan yang didapatkan akibat selisih pengukuran berat sel yang nilainya berdekatan akan lebih besar dari pada pengukuran berat sel secara gravimetris yang nilainya merupakan selisih berat sel pada akhir dan awal percobaan. Alasan yang kedua adalah naptalena padatan yang tidak tersaring pada tahap penyaringan dalam inokulasi awal (preculture) mungkin terbawa dalam media yang dipersiapkan untuk penentuan harga $\mathrm{Y}_{\mathrm{X} / \mathrm{s}}$ sehingga menyebabkan penambahan pertumbuhan sel yang juga berarti kenaikan berat sel. Sedangkan penambahan naptalena padatan yang tidak tersaring ini justru menjadi pengurang dalam penentuan berat naptalena yang dikonsumsi oleh bakteri sehingga didapat harga $Y_{X / S}$ yang lebih besar dari harga yang sebenarnya.

\section{Kurva model utilisasi Naptalena}

Penggambaran kurva model utilisasi naptalena menggunakan persamaan (1). Persamaan ini merupakan persamaan kinetika utilisasi substrat pada pertumbuhan eksponensial. Penentuan penggunaan persamaan (1) dalam simulasi berdasarkan alasan sebagai berikut.

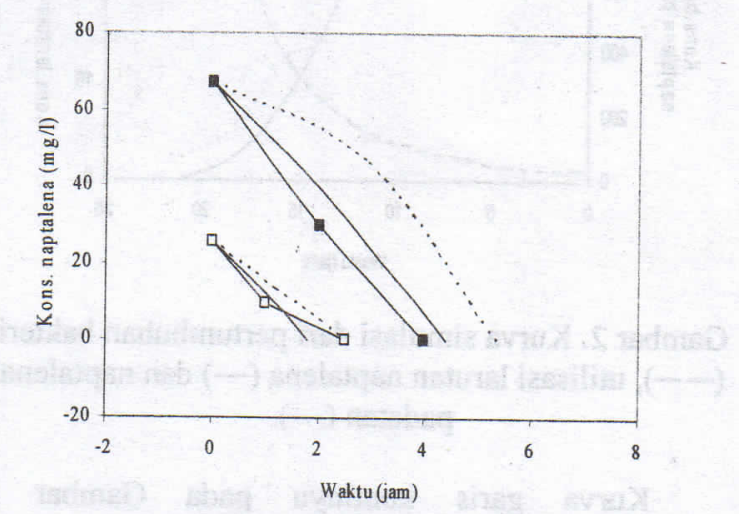

Gambar 1. Kurva model utilisasi naptalena dengan $\mu_{\max }=$ $0,13 \mathrm{jam}^{-1}(--)$ dan $\mu_{\max }=0,20 \mathrm{jam}^{-1}(-)$. Kurva utilisasi naptalena secara percobaan dengan (i) dan tanpa

( $\square$ ) penambahan surfaktan $1 \%(\mathrm{v} / \mathrm{v})$ Tween 80

Harga rata-rata kecepatan pertumbuhan spesifik maksimum $\left(\mu_{\max }\right)$ dari Pseudomonas sp $H B$ yang didapat dari percobaan di laboratorium pada penelitian sebelumnya (Budiastuti, 2004) sebesar 0,13 jam ${ }^{-1}$. Harga ini didapat dari percobaan dengan menggunakan aerasi selama naptalena dikonsumsi oleh bakteri. Harga rata-rata $\mu_{\max }$ yang dihitung berdasarkan persamaan (1) di atas dengan input data percobaan di laboratorium juga menghasilkan harga rata-rata sebesar $0,13 \mathrm{jam}^{-1}$ (Budiastuti, 2004). Pada penelitian ini didapat harga rata-rata $\mu_{\max }$ yang sama yakni sebesar $0,13 \mathrm{jam}^{-1}$ baik dalam bentuk naptalena terlarut maupun naptalena dalam bentuk butiran halus. Harga $\mu_{\max }$ yang persis sama walaupun ditentukan dengan metode yang berbeda menunjukkan bahwa persamaan (1) memenuhi persyaratan keberlakuannya, 
yakni berlaku untuk fase pertumbuhan eksponensial dan untuk konsentrasi naptalena atau substrat (S) yang jauh lebih besar dari harga koefisien saturasinya (Ks). Maka persamaan (1) ini digunakan untuk menggambarkan kurva model utilisasi naptalena (Gambar 1).

\section{Kecepatan pertumbuhan spesifik maksimum $\left(\mu_{\max }\right)$ hasil model}

Penentuan harga $\mu_{\max }$ hasil model berdasarkan kurva utilisasi naptalena yang dibangun menggunakan persamaan (1) di atas dengan input data-data hasil percobaan. Kurva ini (Gambar 1) sudah ditampilkan pada penelitian sebelumnya (Budiastuti, 2005) untuk memperlihatkan pengaruh penambahan surfaktan Tween 80 pada utilisasi naptalena oleh Pseudomonas $s p H B$. Namun kurva ini ditampilkan kembali pada penelitian ini guna kejelasan pemodelan selanjutnya (Gambar 2).

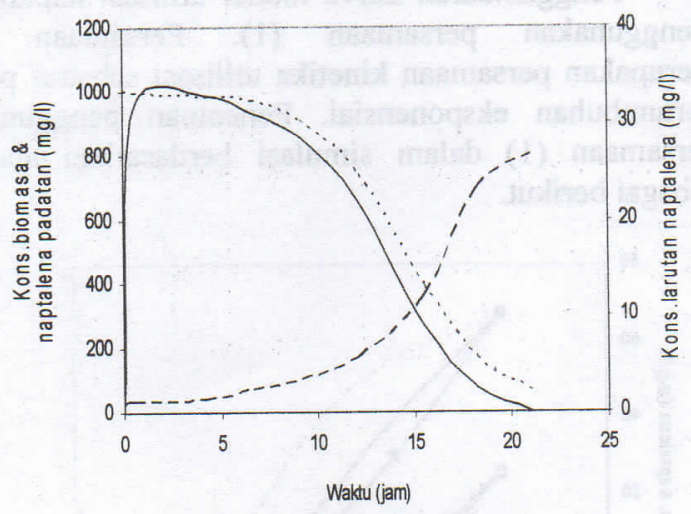

Gambar 2. Kurva simulasi dari pertumbuhan bakteri (- ), utilisasi larutan naptalena (-) dan naptalena padatan (---).

Kurva garis kontinyu pada Gambar 1 memperlihatkan kurva model yang dibangun dengan menggunakan harga $\mu_{\max }$ sebesar $0,20 \mathrm{jam}^{-1}$ sedang kurva garis putus-putus adalah kurva model yang dibangun dengan $\mu_{\max } 0,13 \mathrm{jam}^{-1}$. Kesesuaian yang cukup baik antara ke dua kurva model dengan ke dua kurva utilisasi naptalena tanpa dan dengan penambahan $1 \%(\mathrm{v} / \mathrm{v})$ Tween 80 hasil percobaan

Tabel 2. Parameter-parameter yang digunakan dalam simulasi model. menandakan bahwa kinetika utilisasi naptalena mengikuti kinetika utilisasi substrat pada pertumbuhan eksponensial. Namun kurva model yang dibangun dengan harga $\mu_{\max } \quad 0,20 \mathrm{jam}^{-1}$ lebih sesuai dengan kurva hasil percobaan di laboratorium dari pada kurva model yang dibangun dengan $\mu_{\max } 0,13 \mathrm{jam}^{-1}$. Maka harga $\mu_{\max } 0,20$ jam $^{-1}$ ini dipilih sebagai harga $\mu_{\max }$ untuk pemodelan berikutnya (Gambar 2).

\section{Koefisien perpindahan massa (ka) dan koefisien saturasi (Ks)}

Dengan input harga $\mathrm{Y}_{\mathrm{X} / \mathrm{S}}$ dan $\mu_{\max }$ yang diperoleh di atas, koefisien perpindahan masa (ka) dan koefisien saturasi (Ks) masing-masing dapat ditentukan. Harga parameter-parameter kinetik ini serta data awal untuk input pemodelan (Gambar 2) dapat dilihat pada Tabel 2 .

\section{Simulasi model}

Kurva simulasi dari pertumbuhan bakteri, utilisasi larutan naptalena dan utilisasi naptalena padatan ditunjukkan oleh Gambar 2.

Kurva pertumbuhan bakteri yang meliputi fase lag, fase eksponensial dan fase stasionari dapat dimodelkan secara sempurna. Pelarutan naptalena padatan juga dapat disimulasikan oleh model secara tepat (Gambar 2). Ditunjukkan bahwa fase lag terjadi pada saat awal yakni pada saat pelarutan naptalena berlangsung secara lambat. Pada saat larutan naptalena dikonsumsi secara cepat, pertumbuhan eksponensial terjadi. Fase stasionari dihasilkan pada saat larutan naptalena terkonsumsi habis oleh bakteri Pseudomonas sp $H B$.

Perbandingan kurva pertumbuhan bakteri dan utilisasi larutan naptalena hasil percobaan dengan kurva pertumbuhan bakteri dan utilisasi larutan naptalena hasil simulasi diperlihatkan pada Gambar 3. Lambatnya dikonsumsinya larutan naptalena yang tidak dapat digambarkan oleh model kemungkinan disebabkan oleh fase lag hasil percobaan lebih panjang dari fase lag hasil simulasi. Jika keterlambatn fase lag sebesar 12 jam diperhitungkan maka hasil simulasi akan jauh lebih baik.

\begin{tabular}{llll}
\hline Parameter & Simbol & Harga & Satuan \\
\hline Cell yield & $\mathrm{Y}_{\mathrm{X} / \mathrm{s}}$ & 0,70 & $\mathrm{~g} \mathrm{sel} / \mathrm{g}$ naptalena \\
Kecepatan pertumbuhan maksimum & $\mu_{\max }$ & 0,20 & $\mathrm{jam}^{-1}$ \\
Koefisien perpindahan masa & $\mathrm{ka}$ & 3780 & $\mathrm{jam}$ \\
Koefisien saturasi & $\mathrm{Ks}$ & 1,84 & $\mathrm{mg} / \mathrm{l}$ \\
Konsentrasi biomasa awal & $\mathrm{X}_{0}$ & 28,1 & $\mathrm{mg} / \mathrm{l}$ \\
Konsentrasi awal naptalena padatan & $\mathrm{m}_{0}$ & 1000 & $\mathrm{mg} / \mathrm{l}$ \\
Konsentrasi awal larutan naptalena & $\mathrm{S}_{0}$ & 0,03 & $\mathrm{mg} / \mathrm{l}$ \\
Akurasi & - & 0,001 & - \\
\hline
\end{tabular}


Dari Gambar 3 dapat disimpulkan bahwa penggunaan persamaan (2) dan (3) di atas untuk menghitung harga ka dan Ks adalah tepat dan angkaangka parameter kinetis (Tabel 2) adalah sesuai dengan angka-angka yang dibutuhkan dalam simulasi. Sehingga model matematis yang dibangun dapat memprediksi baik pertumbuhan bakteri maupun utilisasi larutan naptalena dengan akurasi yang cukup tinggi.

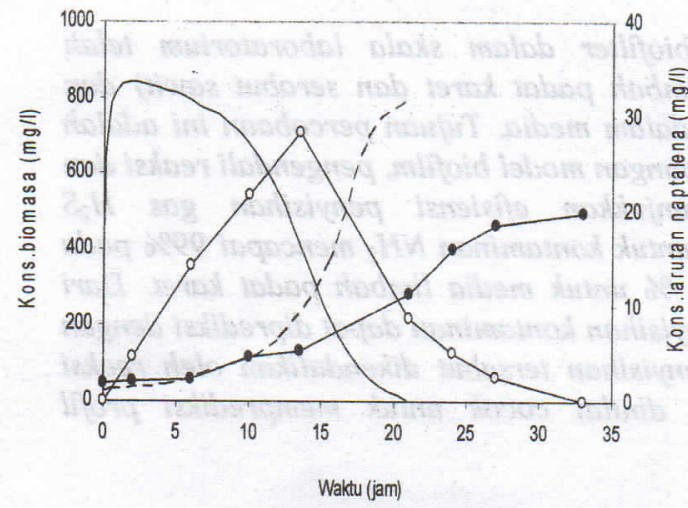

Gambar 3 Kurva pertumbuhan bakteri $(\bullet)$ dan utilisasi larutan naptalena $(0)$ hasil percobaan dengan kurva pertumbuhan bakteri $(-\rightarrow)$ dan utilisasi larutan naptalena (-) hasil simulasi.

\section{Kesimpulan}

Dari hasil pemodelan didapat harga kecepatan pertumbuhan maximum dari Pseudomonas Sp HB $\left(\mu_{\max }\right)$, koefisien perpindahan massa $(\mathrm{ka})$ dan koefisien saturasi (Ks) masing-masing sebesar $0,20 \mathrm{jam}^{-1}, 3780$ jam $^{-1}$, dan $1,84 \mathrm{mg} / 1$.

Penggunaan persamaan (2) dan (3) di atas untuk menghitung harga ka dan $\mathrm{Ks}$ adalah tepat dan angka-angka parameter kinetis (Tabel 2) adalah sesuai dengan angka-angka yang dibutuhkan dalam simulasi.

Model matematis yang dibangun dapat memprediksi pertumbuhan bakteri Pseudomonas $S p$ $H B$ dan utilisasi larutan naptalena oleh bakteri tersebut dengan akurasi yang cukup tinggi.

\section{Saran}

Untuk senyawa beracun dan senyawa yang mempunyai solubilitas rendah, model matematis sangat diperlukan. Manfaat dari terhindarnya peneliti dari kemungkinan terhirupnya uap beracun senyawa tsb dapat diminimalkan dan kesulitan serta waktu yang panjang dalam melakukan percobaan di laboratorium dapat dihindari.

\section{Daftar Notasi}

$\begin{array}{ll}\mathrm{ka} & \text { koefisien perpindahan masa, } \mathrm{jam}^{-1} \\ \mathrm{Ks} & \text { koefisien saturasi, mg/l } \\ \mathrm{m} & \text { konsentrasi naptalena padatan, } \mathrm{mg} / \mathrm{l} \\ \mathrm{m}_{0} & \text { konsentrasi awal naptalena padatan, } \mathrm{mg} / \mathrm{l} \\ \mathrm{N}_{0} & \text { konsentrasi biomasa awal, } \mathrm{mg} / \mathrm{l}\end{array}$

$\mathrm{S} \quad$ konsentrasi larutan naptalena, $\mathrm{mg} / \mathrm{l}$

$\mathrm{S}_{0} \quad$ konsentrasi awal larutan naptalena, $\mathrm{mg} / \mathrm{l}$

$\mathrm{S}_{\mathrm{sat}} \quad$ konsentrasi saturasi naptalena, $\mathrm{mg} / \mathrm{l}$

$\mathrm{t}$ waktu, jam

$\mathrm{X} \quad$ konsentrasi biomasa, $\mathrm{mg} / \mathrm{l}$

$\mathrm{Y}_{\mathrm{X} / \mathrm{S}} \quad$ cell yield, $\mathrm{g}$ biomas/g naptalena

$\rho$ densiti naptalena, $\mathrm{mg} / \mathrm{l}$

$\mu_{\max } \quad$ kecepatan pertumbuhan maksimum, jam $^{-1}$

\section{Daftar Pustaka}

Aitken, M.D., Chen, S.H., Kazunga, C., Marx, R.B., (1997), "Bacterial Biodegradation of High Molecular Weight Polycyclic Aromatic Hydrocarbons", ESE Notes, University of North Carolina, Chapel Hill.

Budiastuti, H., (2004), "Degradasi Naptalena dengan Menggunakan Pseudomonas sp HB”, Fluida, 3(2), 23-28.

Budiastuti, H., (2005), "Pengaruh Penambahan Surfaktan Non-Ionik pada Degradasi Naptalena dengan Menggunakan Pseudomonas sp HB", Prosising Seminar Nasional Rekayasa Kimia dan Proses, Teknik Kimia, Universitas Diponegoro, Semarang.

Edgehill, R., (1992), "Factors Influencing the Success of Bioremediation", Australian Biotechnology, 2(5), 297-301.

Faust, R.A., (1993), "Toxicity Summary for Naphthalene", Oak Ridge Reservation Environmental Restoration Program, Oak Ridge, Tennessee.

Meckenstock, R..U, Annweiler, E., Michaelis, W., Richnow, H.H., and Schink, B., (2000), "Anaerobic Naphthalene Degradation by a Sulfate-Reducing Enrichment Culture", Applied and Environmental Microbiology, 66, 2743-2747.

Mohan, P.K., Nakhla, G., Yanful, E.K., (2005), "Biodegradability of Naphthalene Contaminated Soil under Aerobic, Anoxic and Anaerobic Conditions", International Conference on Energy, Environment and Disasters, Charlotte, NC, USA.

Mueller, J.G, Chapman, P.J., Pritchard, P.H., (1989), "Creosote-contaminated Sites Their Potential for Bioremediation", Environmental Science and Technology, 23(10), 1197-1201.

Mueller, J.G, Middaugh, D.P., Lantz, S.E., Chapman, P.J., 1991, "Biodegradation of Creosote and Pentachlorophenol in Contaminated Ground Water: Chemical and Biological Assessment", Applied and Environmental Microbiology, 57(5), 1277.

Rockne, K.J. and Strand, S.E., (2001), "Anaerobic Biodegradation of Naphthalene, Phenanthrene, and Biphenyl by a Denitrifying Enrichment Culture", Water Research, 35, 291-299. 